\title{
A review of Australian Adenostemma J.R.Forst. \& G.Forst. (Asteraceae: Eupatorieae)
}

\author{
A.E. Orchard \\ c/- Australian Biological Resources Study, GPO Box 787, Canberra ACT 2601, Australia \\ Email: tony.orchard@environment.gov.au
}

\begin{abstract}
The history of regional treatments of the genus Adenostemma in the Australasian region is reviewed, and differing opinions on the taxonomy and nomenclature of taxa thought to occur in Australia and adjacent regions are summarised. In particular, the competing claims of the names A. viscosum and A. lavenia for Australian species are discussed. Examination of most available collections in Australian herbaria has led to the conclusion that the variation is best summarised by recognising three taxa: A. lavenia (L.) Kuntze var. lavenia, A. lavenia var. lanceolatum (Miq.) Koster and A. macrophyllum (Blume) DC. A key, brief diagnostic notes, ecology and distribution are provided for these taxa.
\end{abstract}

\section{Preface}

Surrey Jacobs had a lifelong interest in aquatic plants. Relatively few Asteraceae are aquatic or subaquatic. I trust that he would have found the following discussion of some of the few Australian taxa in this family that are at least facultatively subaquatic to be of interest.

\section{Introduction}

While reviewing Adenostemma for the Flora of Australia it has become apparent that both the taxonomic circumscription and nomenclature of species in this genus are confused and complex. Individual State census lists in Australia (e.g. Porteners 1992, Bostock \& Holland 2007, Kerrigan \& Albrecht 2007, Florabase 1998+) variously refer to essentially the same taxon as A. viscosum, A. lavenia and A. lavenia var. lavenia. Another species, A. macrophyllum, has recently been recognised in Queensland (Stanley 1986, Bostock \& Holland 2007). A number of other names, particularly A. parviflorum (Blume) DC. (syn. Lavenia parviflora Blume; A. viscosum var. parviflora (Blume) Hook.f.) and A. madurense DC. (syn. A. lavenia var. madurense (DC.) Panigrahi) have been caught up in various discussions of synonymy (Koster 1935, 1936; Panigrahi 1975; Grierson 1980; Smith 1991; Koyama 2001, 2002). 
Adenostemma has a pantropical distribution and is commonly stated to have about 20-24 species, e.g. King \& Robinson (1984), Porteners (1992) and Bremer et al. (1994), but according to Koyama (2002) there are up to 30. In Australia there are one, two or three species, depending upon the authority consulted. The following discussion is confined to the taxa found, or thought to occur, in Australia. All are usually considered native to Australia (and to Indonesia and Papua New Guinea immediately to the north). One specimen of A. lavenia var. lavenia was allegedly collected in Australia in 1770 by Banks and Solander, but its provenence is doubtful (see under that taxon).

\section{Taxonomic and nomenclatural history}

In the Australasian region, early authors, following Candolle (1836), tended to recognise a single, variable, pantropical species under the name A. viscosum J.R.Forst. \& G.Forst. Candolle also recognised a large number of regional species, from the Americas, Asia and the East Indies. In the Australasian region, Miquel (1856) added two additional species from Java. Bentham (1866, p. 462) considered that Adenostemma was 'A genus of a very few American species, one of which spreads all round the warmer zone of the globe.' He called this widespread taxon A. viscosum, and commented (p. 463) that 'The species should include all those published by De Candolle and others from the Old World, and at least A. brasiliense and A. triangulare among the American ones.' Subsequent Australian authors followed Bentham's view until the mid-20th century.

Koorders (1912) adopted a similar view to Bentham, and included all Javanese species (including A. parviflorum and A. macrophyllum - see below) under a single name, A. viscosum, which he considered to be pantropical. He recognised no infraspecific taxa

Koster (1935) led a gradual reversal of the broad view of $A$. viscosum when she recognised five species for the Malay Archipelago, of which A. lavenia and A. macrophyllum (Blume) DC. are relevant here. Under her key and descriptions these two taxa overlapped considerably in morphology, and the only clearly distinguishing character was whether the achenes at maturity were densely muricate or more or less smooth. Under A. lavenia she recognised four varieties. Under var. typicum (nom. inval. = var. lavenia) she included as a synonym the name $A$. viscosum. In her discussion of possible type material (Koster 1935, p. 475) she mentioned a specimen in Kew 'on which is written Adenostemma viscosa [sic] (Forster); habitat in Jaheitu' and which she identified as conspecific with $A$. parviflorum (Blume) DC. However, she also stated that a 'type specimen of Adenostemma viscosa [sic]' viewed at the BM 'agrees with the specimens of Adenostemma Lavenia (L.) O.K. examined'. No formal lectotypification was proposed. Adenostemma parviflorum was accepted by her as a distinct taxon, differing mainly in its smaller florets. In a later paper Koster (1966) again accepted A. lavenia and A. macrophyllum, but with slightly different circumscriptions of the names $A$. viscosum and $A$. parviflorum: she accepted A. lavenia, divided into four varieties, with var. lavenia again including A. viscosum, and A. parviflorum reduced to A. lavenia var. parviflorum (Hook.) Hochr.

Backer and Bakhuizen van den Brink (1965) adopted a classification for the Javanese species which was based on that of Koster (1935) and closely resembled that of Koster (1966). They recognised three species: A. hirsutum (not relevant to this discussion), A. macrophyllum, and A. lavenia, and in a footnote stated that A. parviflorum was to be treated as A. lavenia var. parviflorum. The name A. viscosum did not appear, even as a synonym. 
Panigrahi (1975) re-examined typification of names in the complex in the Indian region, finding two type sheets of $A$. viscosum in $\mathrm{K}$ and one in BM (with two specimens). He did not consider Koster's discussion as a lectotypification, and formally lectotypified the name on one of the Kew specimens (now K00009772). This is the specimen that Koster (1935) had identified as A. parviflorum, although, as with Koster, he placed the name A. viscosum in synonymy under A. lavenia var. lavenia. Panigrahi also lectotypified Verbesina lavenia L. (= A. lavenia) on plate 42 in Burman's Thesaurus Zeylanicus (1737) and considered that only Adenostemma lavenia, comprising eight varieties, was present on the Indian mainland. Adenostemma macrophyllum and A. parviflorum were recognised as distinct, but not present in the Indian region.

Grierson (1980) did not cite Panigrahi's paper and may have overlooked it. He provided two typifications. For Verbesina lavenia L. he gave 'Type: Herb. Hermann (BM).' and for Adenostemma viscosum J.R.Forst. \& G.Forst. he gave 'Type: Drawing (BM).' Neither of these statements have status as lectotypifications. He treated A. viscosum as a synonym of A. lavenia, and A. macrophyllum and A. parviflorum as distinct taxa.

King and Robinson (1987) stated that A. lavenia and A. viscosum were distinct, with A. lavenia restricted to its type locality in Sri Lanka, and A. viscosum widespread, from Africa to Sri Lanka, India, Indonesia and the Pacific (as far as Hawai'i according to Smith, 1991). King and Robinson (1987) referred to an earlier paper (King \& Robinson 1974) in which they had reassigned 'A. lavenia' specimens from South America to a number of endemic taxa, and had recognised a segregate taxon of A. viscosum from Fiji. Unfortunately, they did not discuss how A. lavenia s. str. differed from the widespread (and partially sympatric) A. viscosum. They recognised A. lavenia and $A$. viscosum, but not $A$. macrophyllum or A. parviflorum, which were included in their broad A. viscosum. Their (King \& Robinson 1987) list of 24 accepted species omitted Australian taxa, although A. viscosum was listed inter alia as from 'Indonesia, Pacific'.

Smith (1991) apparently also overlooked Panigrahi's paper, and stated under A. viscosum 'The type is J.R.\& G.Forster (BM LECTOTYPE; ISOLECTOTYPE at K), collected on Tahiti, Society Islands, during the second Cook voyage. The BM sheet is marked with a comparatively new label as 'Type specimen', it bears the numbers 172 and 284, the latter being the number under which it was listed by Forster (1786).' This statement has no status as a lectotypification as it is predated by that of Panigrahi (1975). Smith accepted King \& Robinson's (1987) statement about the restriction of A. lavenia s. str. to Sri Lanka, and adopted the name A. viscosum for the Pacific taxon. He did not mention Australian specimens or distribution.

In the most recent regional accounts of the complex, Koyama $(2001,2002)$ recognised A. lavenia var. lavenia from Japan, Taiwan, S. China, SE Asia, India and Sri Lanka, and A. lavenia var. parviflorum from Taiwan, S. China, Thailand, Indonesia (Sumatra), New Guinea and the Pacific (Philippines, Caroline Islands, Hawai'i). Adenostemma macrophyllum was accepted as a distinct species, from 'the Malay archipelago' (specimens cited from Sabah, peninsular Malaysia and from Indonesia (Sumatra and Java)). Adenostemma viscosum J.R.Forst. \& G.Forst. in the sense of its type was excluded from A. lavenia but not discussed further. Unfortunately Koyama seems to have seen no Australian material. 


\section{Naming the Australian taxa}

Almost none of the regional studies of the last century have involved Australian material, and none have looked at a comprehensive range of Australian collections.

In Australian State floras in recent years the names A. lavenia (Stanley 1986, Kerrigan \& Albrecht 2007), A. lavenia var. lavenia (Porteners 1992) and A. viscosum (Lawrence 1992, FloraBase 1998+) have been variously applied to the most widespread taxon, and the name A. macrophyllum has been accepted for some Queensland material (Stanley 1986, Bostock \& Holland 2007).

If King \& Robinson's concept (King \& Robinson 1987, Smith 1991) of the restriction of A. lavenia to Sri Lanka is accepted, then the muricate-achened species in Australia should be given the name A. viscosum. If the views of Koster $(1935,1966)$, Backer \& Backhuizen van den Brink (1965), Panigrahi (1974) and Koyama $(2001,2002)$ of a much wider distribution of $A$. lavenia are accepted, then the correct name for the Australian taxon is A. lavenia (Koster and Panigrahi considered A. viscosum a synonym, Koyama considered it distinct). The consensus view of most Australian herbaria is to accept a broad A. lavenia and this view is adopted here. However, no-one has provided a key or discussion of how, if at all, A. lavenia differs from A. viscosum, and the distributions cited by various authors are suspiciously sympatric.

There is a further problem (although not impacting on Australia) if one accepts infraspecific taxa in A. lavenia. Koster (1935) identified as A. parviflorum the Kew sheet that was subsequently chosen as lectotype of $A$. viscosum by Panigrahi. Adenostemma parviflorum was accepted as a distinct species by Koster (1935), Panigrahi (1975) and Koyama (2002), and as A. lavenia var. parviflorum by Backer and Bakhuizen van den Brink (1965) and Koster (1966). Koster thought that the Forster sheet in BM was 'true' A. viscosum, and thus placed $A$. viscosum in synonymy under A. lavenia var. lavenia. If her identification is accepted and her decision was to be taken as a lectotypification then the correct name for the Forster Tahitian material in K (but not BM), plus some from Malesia, China, Philippines, New Guinea, New Caledonia and Samoa, would be A. parviflorum or A. lavenia var. parviflorum, while the name A. lavenia var. lavenia (as 'var. typicum') was applied by her to other plants distributed from South Asia through Malesia, East Asia (including China and Japan) to Polynesia (including Hawai'i, Samoa, Fiji), and to Australia. No material seen from Australia has achenes or heads as small as those described by Koster $(1935,1966)$ and Koyama (2002) for A. parviflorum/ A. lavenia var. parviflorum, and there is no reason to think that this taxon occurs here.

Panigrahi (1975) identified his lectotype of A. viscosum, the Kew specimen, as A. lavenia var. lavenia, a taxon that he considered extended from Pakistan to Japan and Polynesia. He apparently did not examine Australian material, but it can be assumed that this name (A. lavenia var. lavenia) would also apply to Australian specimens under his classification. Koyama $(2001,2002)$ cited specimens of A. lavenia var. lavenia from Japan, Korea, China, Nepal, Bangladesh, Laos, Cambodia, Vietnam, Thailand, Borneo and Singapore. Eastern Australian material closely matches specimens of this taxon illustrated, keyed and briefly described in Koyama (2001). Koster (1935, 1966) accepted that this taxon extended to Indonesia, New Guinea and Australia, but cited no Australian material. However, it must be remembered that her concept of A. lavenia var. lavenia was based on the BM Forster material, not the K lectotype. In summary, the name A. lavenia var. lavenia can be applied to the small ovate or narrowly ovate leaved, predominantly eastern taxon in Australia. 
Australian material from Western Australia and from the top end of the Northern Territory differs from most eastern specimens, with larger more lanceolate leaves, larger heads and larger achenes. The achenes are brown and muricate when mature, as in A. lavenia var. lavenia. The leaves share with the latter the character of bearing on their upper surface small verrucose white 'cysts', white multicellular structures which seem anatomically to be hair bases (they occasionally extend into short conical hairs). These specimens thus seem to fall within a broad concept of A. lavenia, and match the illustrations and description of A. lavenia var. lanceolatum in Koyama (2001). It is here proposed that this name be adopted for the WA and most NT material. A few, mainly 19th century, collections from Queensland also approach this taxon and are included here. Koyama (2001) cited material from Nepal, Thailand, Borneo and Celebes (Sulawesi) for this taxon, while Koster $(1935,1966)$ considered that it also extended to Sumatra, Java and New Guinea.

The name Adenostemma macrophyllum is accepted for specimens with large broadly ovate leaves, and black achenes which are more or less smooth when mature. It is found in eastern Queensland, principally in the Atherton Tableland /Bellenden Ker region, with an outlier much further south, on Mount Archer and in the Springbrook area of the Moreton Bay region.

Mueller (1860) recorded A. latifolium D.Don for the Burdekin River. This taxon, now A. lavenia var. latifolium (D.Don) Panigrahi, is confined to India, Nepal and Bangladesh, and was almost certainly a misidentification. The specimen on which this record was based has not been relocated, but it probably refers to A. lavenia var. lavenia.

In summary, the following key and simplified synonymy is proposed for this genus in Australia:

\section{Key to Australian taxa of Adenostemma}

1. Leaves ovate or narrowly ovate (lamina 50-70 (-120) $\times(15-) 30-35(-50) \mathrm{mm})$ to lanceolate (lamina then (75-) 130-160 (-200) × 35-60 mm); base acute, tapering gradually to petiole; upper surface dull or slightly shiny when dried, with scattered white cyst-like hair bases; achenes $2.7-3.5 \mathrm{~mm}$ long, brown, densely muricate when mature, sometimes also sparsely glandular 1. A. lavenia

2. Leaves ovate or narrowly ovate, lamina 50-70 (-120) $\times(15-)$ 30-35 (-50) mm; heads c. $8 \mathrm{~mm}$ diam.; achenes $2.7-3.0 \mathrm{~mm}$ long 1a. A. lavenia var. lavenia

2: Leaves lanceolate, lamina (75-) 130-160 (-200) × 35-60 mm; heads c. 9-10 mm diam.; achenes (3.0-) 3.3-3.5 mm long 1b. A. lavenia var. lanceolatum

1: Leaves broadly ovate, lamina (90-) 100-140 (-180) mm long, (40-) 70-85 (-125) mm wide; base truncate to subcordate, then sharply attenuate into petiole; upper surface \pm shiny when dried, lacking cyst-like hair bases; achenes 3.0-3.5 mm long, black, smooth when mature, sometimes also sparsely glandular 2. A. macrophyllum 
1. Adenostemma lavenia (L.) Kuntze, Rev. gen. pl. 1: 304 (1891)

Verbesina lavenia L., Sp. pl. 902 (1753)

Type: Sri Lanka. Lectotype (chosen Panigrahi, 1975): J.Burman, 'Eupatoriophalacron Scrophulariae aquatica foliis oppositis', Thes. zeylan. 95, Plate 42 (1737).

Note: the epithet lavenia is a noun in apposition, probably derived from the Sinhalese vernacular name of the species A. lavenia in Sri Lanka ('Laveniya', see Grierson in Dassanayake and Fosberg, Rev. Handbook Fl. Ceylon 1: 139 (1980)). The generic name is neuter, and thus gives rise to, for example, A. viscosum and A. parviflorum.

\section{1a. Adenostemma lavenia var. lavenia}

Adenostemma viscosum J.R.Forst. \& G.Forst., Char. gen. pl. (edn 2) 90 (1776)

Type: Tahiti. Lectotype (chosen Panigrahi, 1975): Adenostemma viscosum (Forster) Habitaties Taheitee (Presented by Corporation of Liverpool), K00009772 (photo!); isolecto: K00009771 (photo!), BM.

[Adenostemma latifolium auct. non D.Don: F.Mueller, Essay pl. coll. Fitzalan estuary Burdekin 18 (1860)]

An annual or perhaps perennial herb to $60 \mathrm{~cm}$ tall, with stems hollow and rooted only at base, distinguished by its ovate to narrowly ovate leaves (usually 50-70 $\times 30-35$ $\mathrm{mm}$ ), in which the acute base tapers evenly to the upper petiole. The upper surface is dull, and sparsely to densely scattered with small white multicellular cyst-like processes (probably hair bases). The achenes are brown, 2.7-3.0 mm long, with dense thick conical tubercules, glabrous or with scattered short-stalked glandular hairs between the tubercles (the transformation from glandular hairs to tubercles during development of the achene is discussed and illustrated by Koyama (2001)).

Ecology: found in damp spots in cultivated land, and on the edge of rivers and swamps and other watercourses, in alluvial silt, on basalt or granite, at relatively low altitudes from near sea level. Flowers are recorded January to May, fruits March to May.

Distribution: largely confined to areas east of the Dividing Range, from about Cooktown in Queensland to Newcastle in New South Wales, with a few records from the western slopes of the Range. Two records from Settlement Creek and Wollogorang Station in the Gulf country of the Northern Territory seem to be this taxon, although sharing some characteristics of var. lanceolatum. Beyond Australia it is reported from Africa, Pakistan, India, Sikkim, Bhutan, Bangladesh, Nepal, Sri Lanka, Myanmar, Thailand, Singapore, Laos, Cambodia, Vietnam, Japan, Korea, China, Philippines, Indonesia, New Guinea and Polynesia from Borneo to Samoa, Fiji, Tahiti and Hawai'i.

The record of 'A. viscosum' from South Australia in Bentham (1866) ('Entrance to the Murray River, Wilhelmi' [1849]) is based on MEL 717573, a collection determined by Mueller as A. latifolium D.Don. It is A. lavenia var. lavenia, and may have come from the Murray River near Innisfail, N Queensland, or alternatively, is mislabelled. Encounter Bay is a most unlikely location for this pantropical taxon.

1b. Adenostemma lavenia var. lanceolatum (Miq.) Koster, Blumea 1: 474 (1935)

Adenostemma lanceolatum Miq., Fl. Ned. Ind. 2: 24 (1856)

Type: [Indonesia] Java, in Soerakarta, Horsfield, n.v. 
A perennial semisucculent herb to $120 \mathrm{~cm}$ tall, with stems hollow and rooting at the nodes, distinguished by its large lanceolate leaves (usually 130-160 × 35-60 mm), in which the acute base tapers evenly to the upper petiole. The upper surface is dull to almost shiny and sparsely scattered with small white multicellular cyst-like processes. The achenes are similar to those in var. lavenia but slightly larger (usually 3.3-3.5 mm vs $2.7-3.0 \mathrm{~mm}$ long). The capitula are also slightly larger (9-10 $\mathrm{mm}$ diam. vs $8 \mathrm{~mm}$ ).

Ecology: a facultatively semiaquatic or bog-dwelling plant, spreading by rooting from the lower nodes of decumbent stems. Frequently found growing in water to $20 \mathrm{~cm}$ deep, in creeks and swamps, usually on black peaty soils, commonly in rainforest, on basalt and limestone, at low altitudes from near sea level. Flowers and fruits are present from (November-) February to July.

Distribution: found in Western Australia near Kununurra and in the west Kimberley, and in the Northern Territory north of $15^{\circ} 20^{\prime} \mathrm{S}$ from the WA border to eastern Arnhem Land. In Queensland, old (19th century) collections probably representing this taxon are known from eastern Cape York Peninsula, and two recent collections from the Leichhardt region (Carnarvon Gorge National Park, R.J.Fensham 4777, BRI; and Salvator Rosa National Park, R.J. Fensham 3531, BRI) are possibly this taxon. Beyond Australia it is reported from Nepal, Thailand, Indonesia (incl. Java, Sumatra, Celebes and Borneo) and New Guinea.

2. Adenostemma macrophyllum (Blume) DC., Prodr. 5: 113 (1836)

Lavenia macrophylla Blume, Bijdr. Fl. Ned. Ind. 15: 905 (1826)

Type: [Indonesia: Java], Crescit in montanis Gede locis humidis; holo: L?, n.v.

A semi-succulent viscid herb or subshrub to $1 \mathrm{~m}$ tall, distinguished by its broadly ovate leaves (usually $100-140 \times 70-85 \mathrm{~mm}$ ), in which the base is abruptly truncate to subcordate before secondarily tapering shortly and sharply into the upper petiole. The mature achenes are black, rather sticky, and smooth, sometimes with sparse short stalked glandular hairs, but these never develop into conical tubercles. In young or depauperate plants the distinctive truncate leaf base may be less obvious, but the black, smooth achenes are then diagnostic. The shiny upper leaf surface lacking cyst-like hair bases is also distinctive, although that of A. lavenia var. lanceolatum is similar, but less shiny and has the cyst-like processes.

Ecology: found in damp spots in grassy forests, on rainforest margins, roadsides, mud and edges of swamps, on granite, at altitudes of 680-1150 m. Flowers are present April to August (rarely to November), fruits April to November (rarely to January).

Distribution: almost entirely confined to the Atherton Tableland and Rockingham Bay area of north Queensland, with a disjunction to Mount Archer (Leichhardt collection of 1843 ) and the Springbrook region (modern collections) in southeastern Queensland. Beyond Australia it is reported from India, Bangladesh, Malay Peninsula, Indonesia and New Guinea.

The above should be viewed as an interim account. Like other regional treatments over the last century, it does not address variation across the full geographical range of the taxa. If and when this is done as part of a world-wide revision, further adjustments may be necessary. Such a revision should compare Australian material with the many taxa claimed to occur in New Guinea and Indonesia, in particular. 


\section{Acknowledgments}

My thanks to Catherine Jordan at the ANBG library for chasing elusive references for me, to Annette Wilson who provided her usual meticulous comments on a first draft, and to Philip Short for a thorough referee's report.

\section{References}

Backer CA \& Bakhuizen van den Brink RC (1965) Flora of Java, vol. 2: 376. (NVP Nordhoff: Groningen).

Bentham G (1866) Adenostemma, Flora australiensis, vol. 3: 462-463. (L.Reeve \& Co.: Covent Garden). Bostock PD \& Holland AE (2007) Census of the Queensland flora. (Queensland Herbarium: Brisbane). Bremer K, Anderberg AA, Karis PO \& Lundberg J (1994), in Bremer K (ed.), Asteraceae: cladistics \& classification. (Timber Press: Portland, Oregon).

Burman J (1737) Thesaurus zeylanicus, p. 95, pl. 42. (Jansonnius-Waesberg \& Salomon Schouten; Amsterdam).

Candolle AP de (1836) Prodromus systematis naturalis regni vegetabilis, vol. 5: 110-114. (Treutell \& Würtz: Paris).

FloraBase (1998+) Adenostemma. The Western Australian Flora. Department of Environment and Conservation. (http://florabase.dec.wa.gov.au/) (Downloaded 27 Jan. 2010).

Forster G (1786) Florulae Insularum Australianum Prodromus. (Dieterich: Gottingen)

Grierson A (1980) Adenostemma. Pp. 137-140 in Dassanayake MD \& Fosberg FR (eds) A revised handbook of the flora of Ceylon, vol. 1. (A.A.Balkema: Rotterdam).

Kerrigan RA \& Albrecht DE (eds) (2007) Checklist of N.T. vascular plant species. (http://www. nt.gov.au/nreta/wildlife/plants/checklist.html) (Downloaded 27 January 2010).

King RM \& Robinson H (1974) Studies in the Eupatorieae (Asteraceae). CXXVII. Additions to the American and Pacific Adenostemmatineae. Adenostemma, Gymnocoronis and Sciadocephala. Phytologia 29: 1-20.

King RM \& Robinson H (1987) The genera of the Eupatorieae (Asteraceae). Monographs in Systematic Botany from the Missouri Botanical Garden 22. (Missouri Botanic Garden: St Louis).

Koorders SH (1912) Excursionsflora von Java, vol. 3: 316-317. (G.Fischer: Jena).

Koster JT (1935) The Compositae of the Malay Archipelago. Blumea 1: 351-536.

Koster JT (1966) The Compositae of New Guinea. 1. Nova Guinea, Botany 24: 497-614.

Koyama H (2001) Adenostemma lavenia and its allies (Compositae) in Japan, China and Thailand. Memoirs of the National Science Museum, Tokyo 37: 159-168.

Koyama H (2002) Taxonomic studies in the Compositae of Thailand 14. Tribe Eupatorieae. Bulletin of the National Science Museum, Tokyo. Ser. B. 28: 49-60.

Lawrence ME (1992) Adenostemma. Pp. 933-934 in Wheeler JR (ed.), Rye BL, Koch BL \& Wilson AJG, Flora of the Kimberley region. (Western Australian Herbarium: Como).

Miquel FAW (1856) Adenostemma. Pp. 23-26 in Flora Indiae Batavae [Flora van Nederlandsch Indië] vol. 2. (CG van den Post: Amsterdam, $\mathrm{C}$ van den Post: Utrecht, F Fleischer: Leipzig)

Mueller F (1860) Essay on the plants collected by Mr Eugene Fitzalan during Lieut. Smith's expedition to the estuary of the Burdekin: 18. (Government Printer: Melbourne).

Panigrahi G (1975) The genus Adenostemma (Compositae) in the Indian region. Kew Bulletin 30: 647-655.

Porteners MF (1992) Adenostemma. Pp.148-149 in Harden GJ (ed.) Flora of New South Wales, vol. 3. (University of NSW Press: Kensington).

Smith AC (1991) Adenostemma, Flora Vitiensis nova, vol. 5: 291-295. (National Tropical Botanical Garden: Hawai'i).

Stanley TD (1986) Adenostemma. P. 503 in Stanley TD \& Ross EM (eds), Flora of south eastern Queensland, vol. 2. (Queensland Herbarium: Brisbane). 